University of Warwick institutional repository: http://go.warwick.ac.uk/wrap This paper is made available online in accordance with publisher policies. Please scroll down to view the document itself. Please refer to the repository record for this item and our policy information available from the repository home page for further information.

To see the final version of this paper please visit the publisher's website. Access to the published version may require a subscription.

Author(s): S. MUTHUMEENAKSHI, Alan L. GOLDSTEIN, Alison STEWART and John M. WHIPPS

Article Title: Molecular studies on intraspecific diversity and phylogenetic position of Coniothyrium minitans

Year of publication: 2001

Link to published version:

http://dx.doi.org/10.1017/S0953756201004440

Publisher statement: None 


\title{
Molecular studies on intraspecific diversity and phylogenetic position of Coniothyrium minitans
}

\author{
S. MUTHUMEENAKSHI ${ }^{1}$, Alan L. GOLDSTEIN ${ }^{2 *}+$, Alison STEWART ${ }^{2}$ and John M. WHIPPS \\ ${ }^{1}$ Plant Pathology and Microbiology Department, Horticulture Research International, Wellesbourne, Warwick CV35 9EF, UK. \\ ${ }^{2}$ Soil, Plant and Ecological Sciences Division, P.O. Box 84, Lincoln University, Canterbury, New Zealand. \\ E-mail: john.whipps@hri.ac.uk \\ Received 4 September 2000; accepted 30 March 2001.
}

\begin{abstract}
Simple sequence repeat (SSR)-PCR amplification using a microsatellite primer (GACA) ${ }_{4}$ and ribosomal RNA gene sequencing were used to examine the intraspecific diversity in the mycoparasite Coniothyrium minitans based on 48 strains, representing eight colony types, from 17 countries world-wide. Coniothyrium cerealis, $C$. fuckelii and C. sporulosum were used for interspecific comparison. The SSR-PCR technique revealed a relatively low level of polymorphism within C. minitans but did allow some differentiation between strains. While there was no relationship between SSR-PCR profiles and colony type, there was some limited correlation between these profiles and country of origin. Sequences of the ITS 1 and ITS 2 regions and the 5.8S gene of rRNA genes were identical in all twenty-four strains of $C$. minitans examined irrespective of colony type and origin. These results indicate that $C$. minitans is genetically not very variable despite phenotypic differences. ITS and 5.8S rRNA gene sequence analyses showed that $C$. minitans had similarities of $94 \%$ with C. fuckelii and C. sporulosum (which were identical to each other) and only $64 \%$ with $C$. cerealis. Database searches failed to show any similarity with the ITS I sequence for $C$. minitans although the 5.8S rRNA gene and ITS 2 sequences revealed an $87 \%$ similarity with Aporospora terricola. The ITS sequence including the $5.8 \mathrm{~S}$ rRNA gene sequence of Coniothyrium cerealis showed $91 \%$ similarity to Phaeosphaeria microscopica. Phylogenetic analyses using database information suggest that C. minitans, C. sporulosum, C. fuckelii and A. terricola cluster in one clade, grouping with Helminthosporium species and 'Leptosphaeria' bicolor. Coniothyrium cerealis grouped with Ampelomyces quisqualis and formed a major cluster with members of the Phaeosphaeriacae and Phaeosphaeria microscopica.
\end{abstract}

\section{INTRODUCTION}

Coniothyrium minitans is a well-known sclerotial mycoparasite and biocontrol agent of several sclerotium-forming pathogens, mainly species of Sclerotinia and Sclerotium (Campbell 1947, Whipps \& Gerlagh 1992, Grendene \& Marciano 1999). It has been shown to control Sclerotinia sclerotiorum, a widespread soil-borne plant pathogen, in both field and glasshouse trials (Huang 1980, Whipps \& Budge 1990, Budge \& Whipps 1991, Budge et al. 1995, Evenhuis et al. 1995, McQuilken \& Whipps 1995, McQuilken, Budge \& Whipps 1997a, Gerlagh et al. 1999) and currently there are two commercial products, Contans ${ }^{\circledR}$ and KONI (Whipps \& Davies 2000). There has been considerable recent interest in inoculum production, formulation and application (McQuilken, Budge \& Whipps 1997b, c, Weber, Tramper \& Rinzema 1999, 2000), ecology (Williams, Whipps \& Cooke 1998a, b, Jones et al. 1999) and physiology (Smith et al. 1998, 1999, Ooijkaas et al. 1999) of C. minitans.

\footnotetext{
* Corresponding author.

+ Current address: Department of Microbiology, Duke University Medical Center, Durham, NC, 27710, USA.
}

Taxonomically, C. minitans is considered a coelomycetous member of the Leptosphaeriaceae, in the Dothideales (Hawksworth et al. 1995). Campbell (1947) first described C. minitans and Punithalingam (1982) provided a slight modification to the original description. More recently, SandysWinsch et al. (1993) described the world-wide distribution of C. minitans and characterised C. minitans strains into seven groups based on colony morphology and production of pycnidia. However, the variation within these different morphological types of C. minitans derived from an international collection was not assessed further.

Molecular methods involving the production of DNA fingerprints have proved useful tools for analysing genetic diversity in fungi. RAPD, RFLP, AFLP (amplified fragment length polymorphisms), UP-PCR (universally-primed-PCR), AP-PCR (arbitrarily-primed-PCR), ERIC-PCR (enterobacterial repetitive intergenic consensus-PCR) and REP-PCR (repetitive extragenic palindromic-PCR) have all been used with success for a range of fungi (Arora, Hirsch \& Kerry 1996, Chiu et al. 1996, Majer et al. 1996, Bryan et al. 1999, Lübeck et al. 1999). However, in some cases little variation has been detected and reproducibility has been a problem (Majer et al. 1996). Another procedure using simple sequence repeat (SSR) 
DNA sequences as PCR primers was introduced to differentiate 36 yeast isolates into 10 species and 2 genera (Lieckfeldt et al. 1993). Subsequently, a set of six SSR primers and the phage M13 core sequence was used to differentiate over 70 fungal species representing 18 genera of filamentous fungi and five genera of yeasts (Meyer et al. 1993) and this technique has been used more recently to examine diversity in mycorrhizal fungi and Colletotrichum gloeosporiodes (Freeman, Katan \& Shabi 1996, Longato \& Bonfante 1997). These initial studies demonstrated that SSR-PCR was a powerful and easy to employ method for distinguishing large samples of fungal isolates at both the inter and intraspecies level.

Recently, PCR amplification of a dispersed repetitive element (DRE) has been used to distinguish a specific New Zealand isolate of C. minitans (Goldstein et al. 2000). This DRE was initially isolated from a $1.4 \mathrm{~kb}$ RAPD fragment that was specifically amplified in the biological control strain A69. When the RAPD fragment was sequenced it was found to contain two $114 \mathrm{bp}$ direct repeats and a number of shorter 8-11 bp repeated elements. Assays based both upon Southern hybridization using the $1.4 \mathrm{~kb}$ RAPD fragment as a probe, and PCR using primers flanking the $114 \mathrm{bp}$, and shorter repeated elements, were able to produce DNA fingerprints that distinguished $33.3 \%(3 / 9)$ and $39.1 \%(9 / 23)$ of the isolates examined respectively. However, use of other molecular techniques to investigate intraspecific variation in this fungus has not been considered.

Consequently, to determine whether the different morphological types of $C$. minitans could be separated easily on a molecular basis, we used a simple sequence repeat (SSR)-PCR technique using the microsatellite primer $(\mathrm{GACA})_{4}$ to analyse a world-wide collection of over 40 C. minitans strains, including all morphological types, and also sequenced the internal transcribed spacers 1 and 2 and 5.8S rRNA gene from 24 representative strains. Further, as it has been proposed to accommodate C. cerealis, C. fuckelii, C. minitans, and C. sporulosum in a different genus from other species of Coniothyrium on the basis of conidial production (Domsch, Gams \& Anderson 1980, Sutton 1980) we also sequenced single strains of $C$. cerealis and $C$. fuckelii, and two strains of $C$. sporulosum including the ex-type strain. The SSR-PCR technique was also carried out with $C$. fuckelii and $C$. sporulosum. This also enabled some interspecific comparisons to be made. On the basis of this molecular information and that available from databases the relationship between these Coniothyrium species and their phylogeny is described.

\section{MATERIALS AND METHODS}

\section{Fungal strains}

The Coniothyrium strains used in this study are listed in Table 1. The majority were obtained from the culture collections of Horticulture Research International (Sandys-Winsch et al. 1993) and Lincoln University (Goldstein et al. 2000) with two strains of C. minitans, two of C. sporulosum and one each of $C$. cerealis and $C$. fuckelii obtained from CBS (Centraalbureau voor Schimmelcultures, Utrecht). All strains used were characterised and identified according to the criteria of Domsch et al. (1980).
Forty-three strains of C. minitans (encompassing eight colony types originating from 16 countries), two strains of $C$. sporulosum and one of $C$. fuckelii were used in the SSR-PCR based analysis. Twenty-four strains of C. minitans (encompassing eight colony types from 14 countries), two strains of C. sporulosum, and single strains of $C$. cerealis and C. fuckelii were used for ITS sequence analysis. Coniothyrium minitans, $C$. sporulosum, C. fuckelii, and C. cerealis ITS sequences were deposited in GenBank and accession codes are given in Table 2. These sequences were compared in detail to 24 other fungal sequences from databases, the majority of which were chosen for their high similarity value in an Advanced BLAST search using the program supported by NCBI (National Center for Biotechnology Information). These fungal sequences were largely from the Dothideales, encompassing anamorphic and teleomorphic representatives of three families (Leptosphaeriaceae, Phaeosphaeriaceae and Pleosporaceae): Alternaria alternata (GenBank accession code J276059, U05195), Ampelomyces quisqualis (AF126818, AF035783, U82451), Aporospora terricola (AF049088), Helminthosporium species (AF073910, AF120262), Leptosphaeria species (U04203, M96383, M96384, U04207, U04234), Ophiosphaerella species (U04861, AJ246157), Phaeosphaeria species (U77359, U04237, AF181710), Pleospora herbarum (U05202), Phoma species (L38711, AF149934) and Stagonospora arenaria (U77360). ITS sequences of Neurospora crassa (Sordariales, M13906) and Sclerotinia sclerotiorum (Leotiales, M96382) were also included in the analysis as outgroups.

Fungal cultures were maintained on potato dextrose agar (Oxoid) at $20{ }^{\circ} \mathrm{C}$ in the dark. Mycelium for DNA extraction was grown in liquid culture in malt extract medium (Oxoid). Briefly, malt extract liquid medium ( $1 \mathrm{ml}$ ) was placed onto a fully colonised agar plate culture of Coniothyrium and the surface of the culture was disturbed gently to release conidia and mycelial fragments. This inoculum was collected and was added to Petri dishes containing malt extract liquid medium (15 ml). The Petri dishes were incubated at $20^{\circ}$ in dark and after $8-10 \mathrm{~d}$ the fungus formed a uniform mat covering the entire surface of the medium. The mycelial mat was collected aseptically, washed twice with sterile distilled water and lyophilised.

\section{DNA extraction}

Isolation of genomic DNA for microsatellite analysis was carried out as described elsewhere (Goldstein et al. 2000). For ITS amplification and sequencing, DNA was extracted from $100 \mathrm{mg}$ of freeze-dried mycelial powder essentially following the method of Raeder \& Broda (1985) to enable extraction in a $2 \mathrm{ml}$ microfuge tube.

\section{SSR-PCR analysis}

To explore the use of microsatellite primers to detect the intraspecific diversity in Coniothyrium minitans, an initial screening with genomic DNA from three $C$. minitans strains (Cm6, Cm7 and Conio) was carried out using six different microsatellite oligonucleotides, $\left[(\mathrm{CA})_{8^{\prime}}(\mathrm{CT})_{8^{\prime}}(\mathrm{CAC})_{5^{\prime}}(\mathrm{GTG})_{5}\right.$ $(\mathrm{GACA})_{4}$ and $\left.(\mathrm{GATA})_{4}\right]$ as primers. These oligomers were 
Table 1. Strains of Coniothyrium species used for molecular analysis.

\begin{tabular}{|c|c|c|c|c|c|c|c|}
\hline Species & Code & Source $^{\mathrm{a}}$ & Origin & $\begin{array}{l}\text { Colony } \\
\text { type }^{\mathrm{b}}\end{array}$ & $\begin{array}{l}\text { ITS } \\
\text { sequencing }\end{array}$ & $\begin{array}{l}\text { SSR-PCR } \\
\text { group }^{c}\end{array}$ & $\begin{array}{l}\text { DRE } \\
\text { group }^{d}\end{array}$ \\
\hline C. cerealis & CBS 672.68 & CBS & Germany & nd & + & nd & nd \\
\hline C. fuckelii & CBS 132.26 & CBS & Germany & nd & + & l & nd \\
\hline C. minitans & $\mathrm{A} 2 / 206 / 3$ & HRI & Australia & 2 & + & $\mathrm{d}$ & A \\
\hline C. minitans & $\mathrm{A} 2 / 212 / 1$ & HRI & Australia & 2 & nd & $\mathrm{e}$ & nd \\
\hline C. minitans & A2/208/1 & HRI & Australia & 4 & + & $\mathrm{e}$ & A \\
\hline C. minitans & A2/256/1 & HRI & Bulgaria & 4 & + & $\mathrm{d}$ & A \\
\hline C. minitans & $\mathrm{B} / 279 / \mathrm{I}$ & HRI & Canada & 4 & + & nd & nd \\
\hline C. minitans & B/278/1 & HRI & Canada & 5 & + & $\mathrm{b}$ & $\mathrm{E}$ \\
\hline C. minitans & $\mathrm{A} 2 / 330 / 1$ & HRI & Denmark & 5 & nd & $\mathrm{d}$ & nd \\
\hline C. minitans & $\mathrm{A} 1 / 327 / 1$ & HRI & Denmark & 7 & + & $\mathrm{d}$ & A \\
\hline C. minitans & $\mathrm{A} 2 / 1042 / 1$ & HRI & Germany & 1 & + & $\mathrm{d}$ & A \\
\hline C. minitans & $\mathrm{A} 2 / 1030 / 2$ & HRI & Germany & 2 & + & $\mathrm{d}$ & A \\
\hline C. minitans & CBS 641.80 & CBS & Germany & 4 & + & nd & nd \\
\hline C. minitans & C105 & HRI & Germany & 5 & + & $\mathrm{d}$ & A \\
\hline C. minitans & $\mathrm{A} 2 / 506 / 2$ & HRI & Israel & 2 & + & $\mathrm{d}$ & A \\
\hline C. minitans & $\mathrm{A} 2 / 509 / 1$ & HRI & Israel & 2 & nd & $\mathrm{d}$ & nd \\
\hline C. minitans & $\mathrm{A} 2 / 561 / 2$ & HRI & Japan & 2 & + & $\mathrm{d}$ & A \\
\hline C. minitans & $\mathrm{A} 2 / 558 / 3$ & HRI & Japan & 5 & + & $\mathrm{C}$ & $\mathrm{E}$ \\
\hline C. minitans & A2/592/1 & HRI & Korea & 2 & + & nd & nd \\
\hline C. minitans & R391(G8) & HRI & Netherlands & 1 & + & $\mathrm{h}$ & B \\
\hline C. minitans & C10A & HRI & Netherlands & 1 & nd & $\mathrm{h}$ & nd \\
\hline C. minitans & C10 & HRI & Netherlands & 1 & nd & $\mathrm{k}$ & nd \\
\hline C. minitans & $\mathrm{CmMgC9}$ & HRI & Netherlands & 4 & nd & $\mathrm{h}$ & nd \\
\hline C. minitans & G3 & HRI & Netherlands & 4 & nd & $\mathrm{h}$ & nd \\
\hline C. minitans & G4 & HRI & Netherlands & 4 & nd & $\mathrm{h}$ & nd \\
\hline C. minitans & C18 & HRI & Netherlands & 5 & nd & $\mathrm{h}$ & nd \\
\hline C. minitans & $\mathrm{G} 2$ & HRI & Netherlands & 5 & nd & $\mathrm{h}$ & B \\
\hline C. minitans & A70 & Lincoln & New Zealand & 2 & nd & $\mathrm{b}$ & nd \\
\hline C. minitans & $\mathrm{Cm} 7$ & Lincoln & New Zealand & 4 & nd & $\mathrm{a}$ & G \\
\hline C. minitans & $\mathrm{Cm} 8$ & Lincoln & New Zealand & 4 & nd & $\mathrm{g}$ & $\mathrm{H}$ \\
\hline C. minitans & ITS & Lincoln & New Zealand & 4 & nd & i & nd \\
\hline C. minitans & L2E3 & Lincoln & New Zealand & 4 & nd & i & nd \\
\hline C. minitans & TSR42i & Lincoln & New Zealand & 5 & nd & $\mathrm{f}$ & nd \\
\hline C. minitans & TSR42d & Lincoln & New Zealand & 5 & nd & $\mathrm{d}$ & nd \\
\hline C. minitans & ST3 (A71) & Lincoln & New Zealand & 6 & + & $\mathrm{h}$ & B \\
\hline C. minitans & $\mathrm{A} 2 / 704 / 3$ & HRI & Portugal & 2 & nd & $\mathrm{d}$ & nd \\
\hline C. minitans & $\mathrm{A} 2 / 960 / 1$ & HRI & Sao Tome \& Principe & 1 & nd & $\mathrm{d}$ & nd \\
\hline C. minitans & A2/1049/1 & HRI & South Africa & 5 & + & j & I \\
\hline C. minitans & $\mathrm{A} 2 / 787 / 2$ & HRI & Sri Lanka & 1 & + & $\mathrm{d}$ & nd \\
\hline C. minitans & $\mathrm{A} 2 / 792 / 1$ & HRI & Sudan & 1 & + & nd & nd \\
\hline C. minitans & $\mathrm{A} 2 / 806 / 3$ & HRI & Switzerland & 4 & nd & $\mathrm{d}$ & nd \\
\hline C. minitans & $\mathrm{CHI}$ & HRI & UK & 2 & nd & $\mathrm{d}$ & nd \\
\hline C. minitans & CONIO(IMI134523) & HRI & UK & 3 & + & $\mathrm{e}$ & A \\
\hline C. minitans & $\mathrm{CH} 3$ & HRI & UK & 3 & nd & $\mathrm{d}$ & nd \\
\hline C. minitans & $\mathrm{CH} 4$ & HRI & UK & 3 & nd & $\mathrm{e}$ & nd \\
\hline C. minitans & CBS 859.71 & CBS & UK & 4 & + & nd & nd \\
\hline C. minitans & CONIO BUN & HRI & UK (mutant) & 8 & + & $\mathrm{e}$ & A \\
\hline C. sporulosum & CBS 218.68 & CBS & Germany & nd & + & $\mathrm{m}$ & nd \\
\hline C. sporulosum & CBS $358.75 \mathrm{~A}$ & CBS & Netherlands & nd & + & 1 & nd \\
\hline
\end{tabular}

${ }^{a}$ Culture collections: CBS, Centraalbureau voor Schimmelcultures; HRI, Horticulture Research International; Lincoln, Lincoln University.

${ }^{b}$ The colony morphology type of C. minitans is based on Sandys-Winsch et al. (1993). Colony morphology types 1, 2 and 3 are dark-coloured with dense pycnidial numbers; 4, 5, 6 and 7 are light coloured with relatively few pycnidia; 8 is a unique natural mutant derived from CONIO with very restricted mycelial growth.

c SSR-PCR group determined in this study.

${ }^{\mathrm{d}}$ Dispersed repetitive element group based on Goldstein et al. (2000). nd, Not done.

supplied by Life Technologies (Paisley). Based on the number of bands produced and reproducibility of the banding patterns obtained following gel electrophoresis, $(\mathrm{GACA})_{4}$ was chosen to screen the rest of the isolates.
SSR-PCRs were performed in $50 \mu \mathrm{l}$ reactions containing $10 \mathrm{~mm}$ Tris- $\mathrm{HCl}$ (pH 8.3), $50 \mathrm{~mm} \mathrm{KCl}, 3.0 \mathrm{~mm} \mathrm{MgCl}_{2}$, $100 \mu \mathrm{m}$ each $\mathrm{dNTP}, 25 \mathrm{ng}$ primer, $25 \mathrm{ng}$ genomic DNA template and 2.5 U Taq DNA polymerase (Roche Diagnostics, 
Table 2. Characteristics of ITS and 5.8S rRNA gene sequences of Coniothyrium species.

\begin{tabular}{|c|c|c|c|c|c|c|c|c|c|}
\hline \multirow[b]{2}{*}{ Species } & \multicolumn{3}{|c|}{ Length } & \multirow{2}{*}{$\begin{array}{l}\text { GenBank } \\
\text { accession code }\end{array}$} & \multirow[b]{2}{*}{ Species compared } & \multicolumn{4}{|c|}{$\%$ similarity } \\
\hline & ITS 1 & $5.8 \mathrm{~S}$ & ITS 2 & & & ITS 1 & $5.8 \mathrm{~S}$ & ITS 2 & Total \\
\hline C. minitans $(\mathrm{Cm}) \mathrm{CBS} 641-80$ & 195 & 157 & 156 & AJ293809 & $\mathrm{Cm} \rightarrow \mathrm{Cs}$ & 90 & 100 & 97 & 94 \\
\hline C. sporulosum (Cs) CBS 358-75a & 197 & 157 & 156 & AJ293815 & $\mathrm{Cm} \rightarrow \mathrm{Cf}$ & 90 & 100 & 97 & 94 \\
\hline C. fuckelii (Cf) CBS 132-26 & 197 & 157 & 156 & AJ293813 & $\mathrm{Cm} \rightarrow \mathrm{Cc}$ & 69 & 99 & 76 & 66 \\
\hline \multirow[t]{2}{*}{ C. cerealis (Cc) CBS $672-68$} & 191 & 157 & 157 & AJ293812 & $\mathrm{Cs} \rightarrow \mathrm{Cf}$ & 100 & 100 & 100 & 100 \\
\hline & & & & & $\mathrm{Cs} \rightarrow \mathrm{Cc}$ & 65 & 99 & 75 & 65 \\
\hline
\end{tabular}

Lewes). After an initial denaturation for $2 \mathrm{~min}$ at $93^{\circ}$, the reactions were subjected to 40 cycles each consisting of $20 \mathrm{~s}$ at $93^{\circ}, 60 \mathrm{~s}$ at $50^{\circ}$ and $20 \mathrm{~s}$ at $72^{\circ}$, followed by a final extension time of $6 \mathrm{~min}$ at $72^{\circ}$. Each reaction was done twice to check the reproducibility. The PCR products were fractionated on a $1.4 \%$ agarose TAE buffered gel (Sambrook, Fritsch \& Maniatis 1989)

Monomorphic PCR products, or bands, that were in every sample were not scored. All other polymorphic bands were scored binomially irrespective of band intensity as long as the band was consistently present or absent in at least two independent PCR amplifications of the isolate.

\section{PCR amplification of ITS region and sequencing}

The primers ITS 1-ext (5'-GTAACAAGGTTTCCGTAGGTG-3') and ITS4-ext (5'-TTCTTTTCCTCCGCTTATTGATATGC-3') were used to amplify rRNA gene spacers and the $5.8 \mathrm{~S}$ rRNA gene sequence for each strain. $100 \mu \mathrm{l}$ PCR reactions were performed, each containing appropriately diluted genomic DNA ( $10 \mathrm{ng}$ ), I $\times$ reaction buffer (Promega, Southampton), $200 \mu \mathrm{M}$ each of dNTPs, $0.4 \mu \mathrm{M}$ each of primers and $2.5 \mathrm{U}$ of Taq DNA polymerase (Promega). PCR amplification consisted of $94^{\circ}$ for $2 \mathrm{~min}$, followed by 30 cycles of $94^{\circ}$ for $1 \mathrm{~min}, 60^{\circ}$ for $1 \mathrm{~min}$ and $72^{\circ}$ for 1 min and a final extension at $72^{\circ}$ for $10 \mathrm{~min}$.

PCR products were separated electrophoretically and visualised in $1.5 \%(\mathrm{w} / \mathrm{v})$ agarose gels containing ethidium bromide $\left(0.4 \mu \mathrm{g} \mathrm{ml}^{-1}\right)$. PCR products were purified using QIAquick $^{\text {(ii }}$ PCR purification spin columns following the manufacturer's protocol (QIAGEN, Crawley).

Direct sequencing of PCR amplified products was carried out using primers. ITS 1 and ITS4 (White et al. 1990). Sequencing reactions were carried out using the ABI Prism ${ }^{\mathrm{TM}}$ Dye terminator cycle sequencing ready reaction kit $(\mathrm{ABI} /$ Perkin-Elmer). The products were purified by ethanol precipitation following the manufacturer's protocol and nucleotide sequences were determined by the ABI automated sequencing technology.

\section{Data analysis}

The binomial matrix data from the SSR-PCR procedure was analysed with Phylogenetic Analysis using Parsimony (PAUP), version 4.0 software (Swofford, 1999) which uses the cluster analysis of the unweighted pair group method using arithmetic averages (UPGMA). The tree was rooted with two strains of Coniothyrium sporulosum and one of $C$. fuckelii. The length of the tree was computed as the (weighted) sums of the lengths of the individual characters:

$L=\sum_{j=1}^{c} w j l j$,

where $L=$ length of the full tree, $C=$ total number of characters, $w j=$ weighted sums and $l j=$ lengths of weighted characters.

DNA sequences from ITS 1 and ITS 2 regions and the $5.8 \mathrm{~S}$ rRNA gene were edited using the Editseq program (DNASTAR, Madison). DNA sequences were aligned with the programme CLUSTAL W (Thompson, Higgins \& Gibson 1994) of the UWGCG package. All positions were considered for further analysis. The data set consisted of 543 alignable positions in total (the alignment is available from the authors upon request and is accessible from the HRI web site at http://www.hri.ac.uk/site2/research/path/sclerpat/ scleropa.htm). Phylogenetic analyses of the aligned sequences were performed with Distance and Parsimony methods in the PHYLIP package (Felsenstein 1993). DNADIST programme was used to compute distance matrix using Kimura 2parameter model (Kimura 1980). The distance tree was drawn using NEIGHBOR (data not shown). For parsimony analysis, the same multiple alignment used for distance analysis was used to generate 1000 bootstrap resamplings using SEQBOOT to determine the branch support for trees (Felsenstein 1985). DNAPARS was used to search for the best tree by ordinary parsimony. The dataset were subjected to 10 randomisations of sequence input order. The resultant trees were analysed using the program CONSENSE to calculate a majority rule consensus tree. The treefile then was read by TREEVIEW (http://taxonomy.gla.ac.uk/rod/treeview.html; Page 1996) to generate the final dendrogram (Fig. 4). Similarity (\%) between various Coniothyrium spp. and related sequences was calculated using BESTFIT on GCG, Wisconsin.

\section{RESULTS}

\section{SSR-PCR analysis}

Of the six microsatellite primers examined, only (GACA) produced a number of reproducible bands that might be useful for intraspecific differentiation. Of the remaining primers, $(\mathrm{CT})_{8}$ and $(\mathrm{GATA})_{4}$ did not amplify Coniothyrium minitans DNA; $(G T G)_{5}$ produced a smear for all three isolates; $(C A C)_{5}$ did not produce any intraspecific differentiation between the isolates; and $(\mathrm{GA})_{8}$ amplified poorly producing faint PCR products (data not shown). 


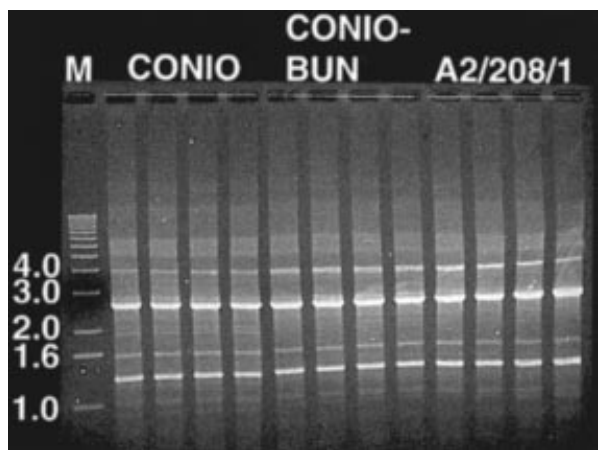

Fig. 1. Microsatellite primer $(\mathrm{GACA})_{4}$ produces reproducible DNA fingerprints in the SSR-PCR technique. Each Coniothyrium minitans strain (Conio, ConioBun and A2/208/1) was amplified in four separate reactions and the reaction products were separated on a $1.4 \%$ agarose TAE gel. The ConioBun and A2/208/1 PCR products were fractionated on a separate gel from the Conio products. $M$, marker.

Primer (GACA) $)_{4}$ was used to amplify genomic DNA from C. minitans strains Conio, ConioBun and A2/208/1. Each strain was amplified in four separately mixed PCR reactions to assess the reproducibility of DNA fingerprints with this microsatellite primer. Fig. 1 shows that $C$. minitans genomic DNA amplified with microsatellite primer $(\mathrm{GACA})_{4}$ produced reproducible fingerprints, even at hybridisation temperatures at $50^{\circ}$. In addition, independent duplicate reactions of $38 \mathrm{C}$. minitans, two $C$. fuckelii and a single $C$. sporulosum isolate were amplified using the (GACA) $)_{4}$ primer and the banding pattern on $1.4 \%$ agarose TAE gels compared, confirming that fingerprints using the microsatellite primer $(\mathrm{GACA})_{4}$ were consistent and reproducible (data not shown). Fig. 2 shows single reactions of each of forty-one samples fractionated in $1.4 \%$ agarose gels in TAE buffer. A total of 11 differently sized bands were observed when all strains of Coniothyrium were considered.

The PAUP analysis software program was used to facilitate grouping strains together that had identical simple sequence repeat profile and each group was assigned a lower case letter group name. The SSR-PCR groups are compared to DRE groups (Goldstein et al. 2000) and colony type in Table 1. The DRE groups were previously assigned an upper case letter group name based upon identical DRE profiles. No attempt was made to match group names between SSR-PCR and DRE profiles. There was generally good agreement between the SSR-PCR groups and DRE groups. For example, all DRE group B strains coincided with SSR-PCR group h strains. In addition, all of the DRE group A strains coincided with SSR-PCR groups $d$ or e. These groups differ only by the presence of an additional $1.4 \mathrm{~kb}$ band in the group $\mathrm{d}$ strains. The separation of DRE group A strains into two SSR-PCR groups suggests that SSRs provide finer resolution of $C$. minitans strains than DREs.

While there was no clear correlation between SSR-PCR profiles and colony type, there was some correlation between these profiles and strain origin. For example, all of the group $h$ and $\mathrm{k}$ strains, with the exception of a single isolate from New Zealand, were from the Netherlands. Nevertheless, other SSR-PCR groups, such as $\mathrm{d}$ and e, contain strains of $C$. (a)

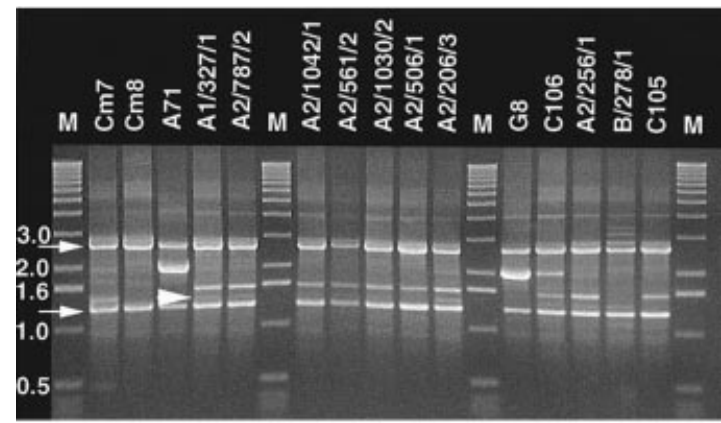

(b)

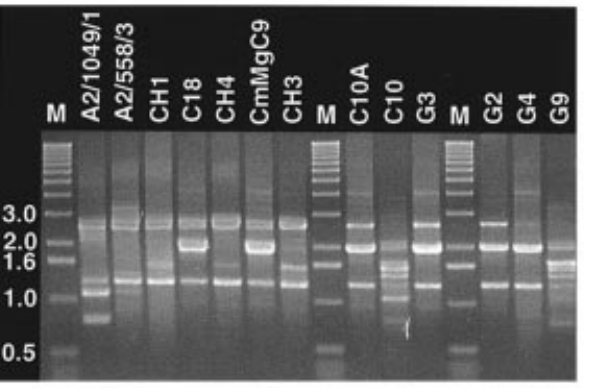

(c)

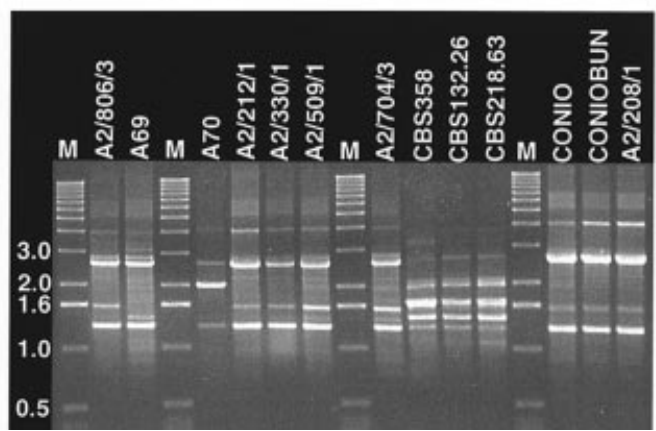

Fig. 2. Products of PCR using microsatellite primer $(\mathrm{GACA})_{4}$ and genomic DNA from Coniothyrium strains. PCR products were fractionated on $1.4 \%$ agarose TAE gels. See Table 1 for strain details. The arrows indicate bands found in every $C$. minitans isolate. The arrowhead shows an example of a faintly amplified band that was nevertheless consistently detected in repeated amplifications. $M$, marker.

minitans from a widely distributed series of countries, so that generalities concerning such SSR-PCR relationships must be treated with caution.

Coniothyrium fuckelii and one strain of C. sporulosum produced identical SSR-PCR profiles (Table 1) but both $C$. sporulosum strains and C. fuckelii were readily distinguishable from C. minitans.

\section{Sequence analysis of ITS region}

The length of the ITS and 5.8S rRNA gene sequences, the GenBank accession codes and the similarity comparisons of the four Coniothyrium species are given in Table 2. The nucleotide sequence of ITS 1-5.8S-ITS 2 region was identical for all twenty-four C. minitans strains used in this study. The sequences of the ITS spacer regions and $5.8 \mathrm{~S}$ gene were identical for the two C. sporulosum strains (CBS 218.68 and CBS $358.75 \mathrm{~A}$ ) and these were well distinguished from $C$. minitans sequence, at $94 \%$ similarity. The sequence from the C. fuckelii strain CBS 132.26 was identical to that of $C$. 




Fig. 3. Alignment of the 5.8S rRNA gene sequences and their flanking internal transcribed spacers (ITS I and ITS 2) of Coniothyrium minitans (CM) CBS 641-80, C. sporulosum (CS) CBS 358-75a and C. cerealis (CC) CBS 672-68. ITS I encompasses bp 1-206; the 5.8S coding region extends from bp 207-363 and the ITS 2 from bp 364-521. A hyphen represents an introduced gap and positions identical in all three sequences are marked with an asterix. The sequences are written $5^{\prime}$ to $3^{\prime}$.

sporulosum. The single strain of C. cerealis CBS 672-68 showed only $65-66 \%$ similarity to C. minitans and C. sporulosum. In general, the base sequence of ITS 1 was more variable than ITS 2 (Table 2).
An alignment of the DNA sequences of ITS 1, ITS 2 and the 5.8S RNA gene of C. minitans, $C$. sporulosum and $C$. cerealis is shown in Fig. 3. The DNA sequence of Coniothyrium cerealis was quite different from that of $C$. minitans and $C$. sporulosum 




Fig. 4. Parsimony tree based on the 5.8S rRNA gene sequences and their flanking internal transcribed spacers (ITS 1 and ITS 2) of Coniothyrium minitans CBS 641-80 (AJ293809), C. sporulosum CBS 358-75a (AJ293815) and C. cerealis CBS 672-68 (AJ293812), closely related species, and outgroups (Neurospora crassa and Sclerotinia sclerotiorum). Majority rule consensus tree generated by the CONSENSE program included in the PHYLIP package. The numbers at the nodes are boostrap values based on 1000 resamplings.

and therefore the alignment contained a large proportion of ambiguously aligned sites. The base composition of ITS spacers and $5.8 \mathrm{~S}$ gene was uniform between C. sporulosum and C. minitans with G-C content ranging from 53 to $55 \%$ but different from that of C. cerealis which had only $46 \%$ G-C content.

To examine the phylogeny of Coniothyrium, a database search was carried out with all three sequences, ITS 1, ITS 2 
and the 5.8S rRNA gene, separately and as a single stretch using the Advanced BLAST search program (NCBI). The search using ITS $I$ of $C$. minitans and $C$. sporulosum did not show similarity to any other sequences in databases, whereas $5.8 \mathrm{~S}$ rRNA gene and ITS 2 spacer region revealed high similarity to Aporospora terricola. BESTFIT of C. minitans sequence including the spacers and $5.8 \mathrm{~S}$ to Aporospora terricola resulted in $87 \%$ identity. C. cerealis sequences showed greatest similarity to Phaeosphaeria microscopica (syn. Leptosphaeria microscopica) (91\% identity).

\section{Phylogenetic analysis}

Coniothyrium minitans, C. sporulosum and Aporospora terricola grouped in one clade in the phylogenetic analysis using both distance (data not shown) and parsimony methods (Fig. 4) and formed a sister group with Helminthosporium spp. and 'Leptosphaeria' bicolor. These two groups were statistically well supported and formed a separate branch from other Leptosphaeriaceae members. In both analysis, Phaeosphaeriaceae (Phaeosphaeria nodorum, P. avenaria and Stagnospora arenaria), Pleosporaceae (Alternaria spp., Pleospora sp.), Leptosphaeriaceae (L. maculans, L. doliolum, and Phoma wasabiae) and Ophiosphaerellaceae formed tight clusters. The only strain of $C$. cerealis used in this study did not group with other species of Coniothyrium but was strongly supported as a clade with Ampelomyces quisqualis, a mitosporic fungus, and formed a major cluster with other Phaeosphaeriaceae members.

\section{DISCUSSION}

The appropriateness of any DNA-fingerprinting technique relies upon the ability of the technique to reflect genetic distances between individuals (Soll 2000). One way to assess whether a DNA-fingerprinting technique fulfils this requirement is to compare the data produced by that method with data produced by an unrelated method (Tibayrenc et al. 1993, van Belkum et al. 1994, Pujol et al. 1997). To this end we compared the relatedness of Coniothyrium minitans isolates by both SSR-PCR and with an unrelated dispersed repetitive element (DRE) (Goldstein et al. 2000). In the experiments reported here, $25.6 \%$ (11/43) of the isolates had unique DNA fingerprints using the $(\mathrm{GACA})_{4}$ primer. Importantly, as described in the Results section, there was excellent agreement between genetic distances assigned by SSR-PCR and DRE fingerprinting. For example, the two largest DRE groups, A and B, were completely contained within SSR-PCR groups $h$ and $d$ or e respectively. Since SSR-PCR could resolve the largest DRE fingerprinting group into two groups, it appears that SSRs provides better resolution of $C$. minitans isolates than DREs. Furthermore, the fact that these two independent means of assaying genetic relatedness agree closely, validates the use of SSR-PCR to distinguish C. minitans isolates and strongly supports the hypothesis that there is little worldwide genetic diversity in this species. There were no polymorphisms in the ITS region of $C$. minitans as the sequences were identical in all 26 strains examined despite being of wide geographical origin and differing colony type. This further indicates that genetic diversity is limited amongst
C. minitans strains and that which is present in these genetic regions is not related to phenotype or place of origin.

The degree of intraspecific variation in the ITS region can vary considerably in different fungi. For example, it has been found to be highly variable in some such as Beauveria brongniartii (Neuveglise et al. 1994), Colletotrichum lindemuthianum (Balardin et al. 1999), Fusarium fujikuroi (O' Donnell \& Cigelnik 1997), Metarhizium anisopliae (Curran et al. 1994), Puccinia monoica (Roy et al. 1998), and some groups of Trichoderma harzianum (Muthumeenakshi et al. 1994), or very conserved in others including Oidiodendron maius (Hambleton et al. 1998), some Penicillium species (LoBuglio et al. 1994), Phytophthora quercina (Cooke et al. 1999), and some other groups of Trichoderma harzianum (Muthumeenakshi et al. 1998). However, the finding that strains of species from geographically distinct areas have identical ITS sequences as with C. minitans in this study and with some Ascosphaera species (Anderson et al. 1998) are rare. This begs the question of the reason for this conservation. One possibility is that $C$. minitans is a relatively new species having recently overcome some constraint or bottleneck that has subsequently allowed rapid spread. In part, this may be related to the specialised life cycle of Coniothyrium minitans. It is an ecologically obligate necrotrophic mycoparasite and is restricted to growth in host sclerotia or plant tissues infected by Sclerotinia species. In the absence of its host, C. minitans survives in soil as conidia although it can be dispersed by rain splash and mesofauna (Whipps \& Gerlagh 1992, Williams et al. 1998a, b). This could suggest that the world-wide distribution of $C$. minitans is associated with the spread of its host Sclerotinia species and susceptible crops. Another possible reason for the low levels of polymorphism is that the species reproduces asexually only.

The SSR-PCR technique and ITS sequencing demonstrated that $C$. minitans was closely related to both $C$. fuckelii and $C$. sporulosum but the latter two species were virtually identical based on data from both molecular tests. Domsch et al. (1980) noted that $C$. sporulosum and C. fuckelii were indistinguishable on the basis of conidial characteristics and our work corroborates the view that these species may be conspecific. Coniothyrium cerealis was less closely related to $C$. minitans, $C$. sporulosum and C. fuckelii (65-66\% similarity based on ITS sequencing) and also appeared in a different lineage in the phylogenetic analysis although more strains would need to be examined to be certain of this difference in lineage.

Coniothyrium is currently considered an anamorphic member of the Leptosphaeriaceae with Leptosphaeria as teleomorph (Hawksworth et al. 1995). However, no teleomorphic stage has been reported for C. minitans. We included Leptosphaeria species and other dothidealean fungi from databases in our phylogenetic analysis to determine the relationship of the Coniothyrium species used in this study. Leptosphaeriaceae (Leptosphaeria species with Phoma as their anamorph), Pleosporaceae (Pleospora and Alternaria) and Ophiosphaerella species were well distinguished by phylogenetic analysis and this result agrees with previous analyses (Morales et al. 1995, Jasalavich et al. 1995). Phylogenetic analysis indicates the distinct phylogenetic position of C. minitans and C. sporulosum from other Leptosphaeriaceae, Pleosporaceae and Phaeo- 
sphaeriaceae. The closest relationship of these two Coniothyrium species was with Aporospora terricola but little information other than the sequence and culture deposition data appear available for this species. Morales et al. (1995) distinguished 'L.' bicolor as a separate group phylogenetically distant from Leptosphaeriaceae, and, interestingly, C. minitans and C. sporulosum formed a sister group with ' $L$.' bicolor with a high bootstrap value in our analysis. The only strain of $C$. cerealis used in our study grouped with Ampelomyces and was placed along with other Phaeosphaeriaceae. Our study also indicates that $C$. cerealis is more closely related to Phaeosphaeria nodorum and P. microscopica than to the other Coniothyrium species. Even though the conidial formation was found to be sparse, we are confident that $C$. cerealis culture used in this study matched the description (Domsch et al. 1980). Consequently, it would appear from our studies that $C$. cerealis is phylogenetically distinct from C. minitans, C. fuckelii and $C$. sporulosum.

In general, our tree extends the phylogeny of Leptosphaeriaceae and Phaeosphaeriaceae by the placement of four anamorphic Coniothyrium species. The genus Coniothyrium consists of a large number of species and so, it is not surprising to see a polyphyletic nature of this anamorphic genus. More molecular characterisation studies on a greater number of species and strains of Coniothyrium, as well as the closely related Microsphaeropsis (Morgan-Jones 1974, Sutton 1980), is required to establish the phylogeny of this genus.

\section{ACKNOWLEDGEMENTS}

We would like to thank the Biotechnology and Biological Sciences Research Council and The New Zealand Foundation for Research Science and Technology for financial support. A.L.G. received invaluable assistance from Jianping $\mathrm{Xu}$. We also thank Tom Mitchell for helpful discussions.

\section{REFERENCES}

Anderson, D. L., Gibbs, A. J. \& Gibson, N. L. (1998) Identification and phylogeny of spore-cyst fungi (Ascosphaera spp.) using ribosomal DNA sequences. Mycological Research 102 : 541-547.

Arora, D. K., Hirsch, P. R. \& Kerry, B. R. (1996) PCR-based molecular discrimination of Verticillium chlamydosporium isolates. Mycological Research 100: 801-809.

Bryan, G. T., Labourdette, E., Melton, R. E., Nicholson, P., Daniels, M. J. \& Osbourn, A. E. (1999) DNA polymorphism and host range in the take-all fungus, Gaeumannomyces graminis. Mycological Research 103: 319-327.

Budge, S. P., McQuilken, M. P., Fenlon, J. S. \& Whipps, J. M. (1995) Use of Coniothyrium minitans and Gliocladium virens for biocontrol of Sclerotinia sclerotiorum in glasshouse lettuce. Biological Control 5 : 513-522.

Budge, S. P. \& Whipps, J. M. (1991) Glasshouse trials of Coniothyrium minitans and Trichoderma species for the biological control of Sclerotinia sclerotiorum in celery and lettuce. Plant Pathology 40: 59-66.

Campbell, W. A. (1947) A new species of Coniothyrium parasitic on sclerotia. Mycologia 39: 190-195.

Chiu, S.-W., Ma, A.-M., Lin, F.-C. \& Moore, D. (1996) Genetic homogeneity of cultivated strains of shiitake (Lentinula edodes) used in China as revealed by the polymerase chain reaction. Mycological Research 100: 1393-1399.

Cooke, D. E. L., Jung, T., Williams, N. A., Schubert, R., Bahnweg, G., Obwald, W. \& Duncan, J. M. (1999) Molecular evidence supports Phytophthora quercina as a distinct species. Mycological Research 103: 799-804.

Curran, J. F., Driver, J.W., Ballard, O. \& Milner, R. H. (1994) Phylogeny of Metarhizium: analysis of ribosomal DNA sequence data. Mycological Research 98: 547-552.
Domsch, K. H., Gams, W. \& Anderson, T.-H. (1980) Compendium of Soil Fungi. Academic Press, London.

Evenhuis, A., Verdam, B., Gerlagh, M. \& Goosen-van de Geijn, H. M. (1995) Studies on major diseases of caraway (Carum carvi) in the Netherlands. Industrial Crops and Products 4: 53-61.

Felsenstein, J. (1985) Confidence limits on phylogenies: an approach using the bootstrap. Evolution 39: 783-791.

Felsenstein, J. (1993) PHYLIP (Phylogeny Inference Package). Version 3.5c. University of Washington, Seattle.

Freeman, S., Katan, T. \& Shabi, E. (1996) Characterization of Colletotrichum gloeosporioides isolates from avocado and almond fruits with molecular and pathogenicity tests. Applied and Environmental Microbiology 62 : 1014-1020. Gerlagh, M., Goosen-van de Geijn, H. M., Fokkema, N. J. \& Vereijken, P. F. G. (1999) Long-term biosanitation by application of Coniothyrium minitans on Sclerotinia sclerotiorum-infected crops. Phytopathology 89: 141-147.

Goldstein, A. L., Carpenter, M. A., Crowhurst, R. N. \& Stewart, A. (2000) Identification of Coniothyrium minitans isolates using PCR amplification of a dispersed repetitive element. Mycologia 92: 46-53.

Grendene, A. \& Marciano, P. (1999) Interaction between Sclerotinia sclerotiorum and Coniothyrium minitans strains with different aggressiveness. Phytoparasitica 27: 201-206.

Hambleton, S., Egger, K. N. \& Currah, R. S. (1998) The genus Oidiodendron: species delimitation and phylogenetic relationships based on nuclear ribosomal DNA analysis. Mycologia 90: 854-869.

Hawksworth, D. L., Kirk, P. M., Sutton, B. C. \& Pegler, D. N. (1995) Ainsworth \& Bisby's Dictionary of the Fungi. 8th edn. CAB International, Wallingford.

Huang, H. C. (1980) Control of Sclerotinia wilt of sunflower by hyperparasites. Canadian Journal of Plant Pathology 2 : 26-32.

Jasalavich, C. A., Morales, V. M., Pelcher, L. E. \& Seguin-Swartz, G. (1995) Comparison of nuclear ribosomal DNA sequences from Alternaria species pathogenic to crucifers. Mycological Research 99: 604-615.

Jones, E. E., Carpenter, M., Fong, D., Goldstein, A., Thrush, A., Crowhurst, R. \& Stewart, A. (1999) Co-transformation of the sclerotial mycoparasite Coniothyrium minitans with hygromycin B resistance and B-glucuronidase markers. Mycological Research 103: 929-937.

Kimura, M. (1980) A simple method for estimating evolutionary rate of base substitutions through comparative studies on nucleotide sequences. Journal of Molecular Evolution 2: 87-90.

Kuhls, K., Lieckfeldt, E., Samuels, G. J., Meyer, W., Kubicek, C. P. \& Borner, T. (1997) Revision of Trichoderma sect. Longibrachiatum including related teleomorphs based on analysis of ribosomal DNA internal transcribed spacer sequences. Mycologia 89: 442-460.

Lieckfeldt, E., Meyer, W. \& Börner, T. (1993) Rapid identification and differentiation of yeasts by DNA and PCR fingerprinting. Journal of Basic Microbiology 33: 413-426.

LoBuglio, K. F., Pitt, J. I. \& Taylor, J. W. (1994) Independent origins of the synnematous Penicillium species, P. duclauxii, P. clavigerum and P. vulpinum as assessed by two ribosomal DNA regions. Mycological Research 98: 250-256.

Longato, S. \& Bonfante, P. (1997) Molecular identification of mycorrhizal fungi by direct amplification of microsatellite regions. Mycological Research 101: 425-432.

Lübeck, M., Alekhina, I. A., Lubeck, P. S., Funck Jensen, D. \& Bulat, S. A. (1999) Delineation of Trichoderma harzianum into two different genotypic groups by a highly robust fingerprinting method, UP-PCR, and UP-PCR product cross-hybridization. Mycological Research 103 : 289-298.

Majer, D., Mithen, R., Lewis, B. G., Vos, P. \& Oliver, R. P. (1996) The use of AFLP fingerprinting for the detection of genetic variation in fungi. Mycological Research 100: 1107-1111.

McQuilken, M. P., Budge, S. P. \& Whipps, J. M. (1997a) Effects of culture media and environmental factors on conidial germination, pycnidial production and hyphal extension of Coniothyrium minitans. Mycological Research 101: 11-17.

McQuilken, M. P., Budge, S. P. \& Whipps, J. M. (1997b) Production, survival and evaluation of liquid culture-produced inocula of Coniothyrium minitans against Sclerotinia sclerotiorum. Biocontrol Science and Technology 7: 23-36.

McQuilken, M. P., Budge, S. P. \& Whipps, J. M. (1997c) Biological control of Sclerotinia sclerotiorum by film-coating Coniothyrium minitans on seed and sclerotia. Plant Pathology 46: 919-929. 
McQuilken, M. P. \& Whipps, J. M. (1995) Production, survival and evaluation of solid-substrate inocula of Coniothyrium minitans against Sclerotinia sclerotiorum. European Journal of Plant Pathology 101: 101-110.

Meyer, W., Lieckfeldt, E., Kuhls, K., Freedman, E. Z., Börner, T. \& Mitchell, T. G. (1993) DNA- and PCR-fingerprinting in fungi. In DNA Fingerprinting: state of the science (S. D. J. Pena, R. Chakraborty, J. T. Epplen \& A. J. Jeffreys, eds): 311-320. Birkhäuser Verlag, Basel.

Morales, V. M., Jasalavich, C. A., Pelcher, L. E., Petrie, G. A. \& Taylor, J. L. (1995) Phylogenetic relationship among several Leptosphaeria species based on their ribosomal DNA sequences. Mycological Research 99: 593-603.

Morgan-Jones, G. (1974) Concerning some species of Microsphaeropsis. Canadian Journal of Botany 52 : 2575-2579.

Muthumeenakshi, S., Mills, P. R., Brown, A. E. \& Seaby, D. A. (1994) Intraspecific molecular variation among Trichoderma harzianum isolates colonizing mushroom compost in the British Isles. Microbiology 140: $769-777$.

Muthumeenakshi, S., Mills, P. R. \& Brown, A. E. (1998) Genetic comparison of the aggressive weed mould strains of Trichoderma harzianum from mushroom compost in North America and the British Isles. Mycological Research 102: 385-390.

Neuveglise, C., Brygoo, Y., Vercambre, B. \& Riba, G. (1994) Comparative analysis of molecular and biological characteristics of strains of Beauveria brongniartii isolated from insects. Mycological Research 98 : 322-328.

O'Donnell, K. \& Cigelnik, E. (1997) Two divergent intragenomic rDNA ITS 2 types within a monophyletic lineage of the fungus Fusarium are nonorthologous. Molecular Phylogenetics and Evolution 7: 103-116.

Ooijkaas, L. P., Wilkinson, E. C., Tramper, J. \& Buitelaar, R. M. (1999) Medium optimization for spore production of Coniothyrium minitans using statistically-based experimental designs. Biotechnology and Bioengineering 64: 92-100

Page, R. D. M. (1996) TREEVIEW: An application to display phylogenetic trees on personal computers. Computer Applications in the Biosciences 12: 357-358

Pujol, C., Joly, S., Lockhart, S., Noel, S., Tibayrenc, M. \& Soll, D. R. (1997) Parity of MLEE, RAPD and Ca3 hybridization as fingerprinting methods for Candida albicans. Journal of Clinical Microbiology 35 : 2348-2358.

Punithalingam, E. (1982) Coniothyrium minitans. CMI Descriptions of Pathogenic Fungi and Bacteria 732 : 1-2.

Raeder, U. \& Broda, P. (1985) Rapid preparation of DNA from filamentous fungi. Letters in Applied Microbiology 1 : 17-20.

Roy, B. A., Vogler, D. R., Burns, T. D. \& Szaro, T. M. (1998) Cryptic species in the Puccinia monoica complex. Mycologia 90: 846-853.

Sambrook, J., Fritsch, E. F. \& Maniatis, T. (1989) Molecular Cloning -A Laboratory Manual. Cold Spring Harbor Press, Cold Spring Harbor, NY.

Sandys-Winsch, C., Whipps, J. M., Gerlagh, M. \& Kruse, M. (1993) World distribution of the sclerotial mycoparasite Coniothyrium minitans. Mycological Research 97: 1175-1178.

Smith, S. N., Armstrong, R. A., Barker, M., Bird, R. A., Chohan, R., Hartel, N. A. \& Whipps, J. M. (1999) Determination of Coniothyrium minitans conidial and germling lectin affinity by flow cytometry and digital microscopy. Mycological Research 103: 1533-1539.

Smith, S. N., Chohan, R. A., Armstrong, R. A. \& Whipps, J. M. (1998) Hydrophobicity and surface charge of conidia of the mycoparasite Coniothyrium minitans. Mycological Research 102: 243-249.

Soll, D. R. (2000) The ins and outs of DNA fingerprinting the infectious fungi. Clinical Microbiological Reviews 13: 332-370.

Sutton, B. C. (1980) The Coelomycetes. Commonwealth Mycological Institute, Kew, Surrey.

Swofford, D. L. (1999) PAUP: Phylogenetic Analysis using Parsimony. Version 4.0. Sinauer Associates, Sunderland, MA.

Thompson, J. D., Higgins, D. G. \& Gibson, T. J. (1994) CLUSTAL W: improving the sensitivity of progressive multiple sequence alignment through sequence weighting, positions-specific gap penalties and weight matrix choice. Nucleic Acids Research 22 : 4673-4680.

Tibayrenc, M., Neubauer, K., Barnabé, C., Guerrini, F., Skarecky, D. \& Ayala, F. J. (1993) Genetic characterization of six parasitic protozoa: parity between random-primer DNA typing and multilocus enzyme electrophoresis. Proceedings of the National Academy of Sciences, USA 90: 1335-1339.

van Belkum, A., Melchers, W., de Pauw, B. E., Scherer, S., Quint, W. \& Meis, J. F. (1994) Genotypic characterization of sequential Candida albicans isolates from fluconazole-treated neutropenic patients. Journal of Infectious Disease 169: 1062-1070.

Weber, F. J., Tramper, J. \& Rinzema, A. (1999) A simplified material and energy balance approach to process development and scale-up of Coniothyrium minitans conidia production by solid-state cultivation in packed-bed reactor. Biotechnology and Bioengineering 65 : 447-458.

Weber, F. J., Tramper, J. \& Rinzema, A. (2000) Effect of the availability of magnesium ions in K-carrageenan gels on the formation of conidia by Coniothyrium minitans. Mycological Research 104: 73-76.

Whipps, J. M. \& Budge, S. P. (1990) Screening for sclerotial mycoparasites of Sclerotinia sclerotiorum. Mycological Research 94: 607-612.

Whipps, J. M. \& Davies, K. G. (2000) Success in biological control of plant pathogens and nematodes by microorganisms. In Measures of Success in Biological Control (G. Gurr \& S. D. Wratten, eds): 231-269. Kluwer Academic Publishers, Dordrecht.

Whipps, J. M. \& Gerlagh, M. (1992) Biology of Coniothyrium minitans and its potential for use in disease biocontrol. Mycological Research 96: 897-907.

White, T. J., Bruns, T., Lee, S. \& Taylor, J. (1990) Amplification and direct sequencing of fungal ribosomal RNA genes for phylogenetics. In PCR Protocols: A guide to methods and applications (M. A. Innis, D. H. Gelfand, J. J. Sninsky \& T. J. White, eds): 315-322. Academic Press, San Diego.

Williams, R. H., Whipps, J. M. \& Cooke, R. C. (1998a) The role of soil mesofauna in dispersal of Coniothyrium minitans: mechanisms of transmission. Soil Biology and Biochemistry 30: 1937-1945.

Williams, R. H., Whipps, J. M. \& Cooke, R. C. (1998b) Splash dispersal of Coniothyrium minitans in the glasshouse. Annals of Applied Biology 132: 77-90.

Corresponding Editor: R. S. Currah 